\title{
Effects of predation pressure on bacterial abundance, diversity, and size-structure distribution in an oligotrophic system
}

\author{
Gianluca CORNO*, Emanuele CARAVATI, Cristiana CALLIERI, and Roberto BERTONI \\ CNR, Institute of Ecosystem Study, 28922 Verbania-Pallanza, Italy \\ *e-mail corresponding author: g.corno@ise.cnr.it
}

\begin{abstract}
We designed microcosm experiments to study the response of bacterial communities to altered predation pressure, in phosphorus-limited conditions. Different-sized predators were removed through filtration, yielding the following treatments: bacteria only (no predation, $N P ;<1 \mu \mathrm{m}$ filtrate); small-sized predators $(10 P,<10 \mu \mathrm{m}$ filtrate) and small- to medium-sized predators present (50P, <50 $\mu \mathrm{m}$ filtrate). Natural control (NC) included predators of all sizes. Thus we compared the relative impact of differential predation on abundance, biovolume, community composition and size-structure distribution of bacterial assemblages subject to grazing by different-sized predators. The relative diversity of microbial communities was estimated by a fingerprinting based approach for both prey and predators. The results showed that the presence of grazers preserved the Shannon diversity of the bacterial community and shifted the size-structure distribution towards grazing-resistant forms. Absence of predation promoted competition for resources and resulted in a constant reduction of the relative diversity of the bacterial community. The change in the size-structure distribution of the bacterial communities in the treatments was accompanied by alterations in the relative operational taxonomic unit (OTU) composition of the eukaryotic and bacterial communities. Bacterial OTUs grouped in two distinct fractions linked to their size-structure distribution, in dependence to the presence of the predators: Small and Edible cells were favoured by low grazing pressure whereas Filaments and Aggregates were stimulated by predator presence. Eukaryotic OTUs successful at high grazing activity resulted as rather different than OTUs successful at lower degree of grazing. Under high protistan grazing pressure, there was a clear shift in bacterial community composition regarding both size-structure distribution and genotypes. Nevertheless, diversity was preserved. The opposite situation characterized the predator-free bacterial communities; a clear and constant reduction of the community diversity was indicated, confirming that moderate top-down control is fundamental to the shaping and preservation of natural bacterial communities, even in oligotrophic systems.
\end{abstract}

Key words: top-down impact, prey-predator interaction, bacterial diversity, microcosm experiment, ARISA

\section{INTRODUCTION}

The relative importance of top-down and bottom-up factors in controlling abundance, biomass, and productivity of aquatic bacteria has been investigated extensively during the last two decades (for reviews, see Jürgens \& Güde 1994; Gasol et al. 2002), yet a general consensus on which group of factors is more important in determining size and structure of a bacterial community is lacking (Pernthaler 2005).

Early studies suggested that top-down pressure on bacterial assemblages increases with lake trophic state. Thus, oligotrophic systems (alpine lakes as well as open oceans) were taken to be more bottom-up controlled (Sanders et al. 1992) than waters richer in nutrients. After enlarging the available environmental dataset, Gasol and co-workers (2002) reached the opposite conclusion, that bacterial abundance and growth generally are regulated by predation in the most oligotrophic environments. In the richest environments protist predation affects more specifically bacterial community composition.

Experimental studies showed that the impact of predation on bacterial communities sometimes is relieved by high nutrient availability. In this situation, some bacteria develop at such extremely high growth rates (Šimek et al. 2003) that they establish large populations even under high predation pressure. Furthermore, a nutrient-rich system can sustain a larger community of top predators that control the abundance of bacterivorous predators and thus release the bacterial community from predation control (Pernthaler 2005). Interactions between grazing pressure and availability of nutrients are not only regulated by reduced protist prey numbers due to predation by top predators, but also by the stimulation of bacterial growth (in abundance and biomass) that results from nutrient recycling by grazers (Pernthaler et al. 1997; Corno \& Jürgens 2006).

Even in the presence of a large number of possible predators, (ciliates, Sherr \& Sherr 1987; filter-feeding planktonic cladocerans, Jürgens 1994; gelatinous zooplankton Bedo et al. 1993; benthic organisms Gili \& Coma 1998), hetero- and mixotrophic nanoflagellates generally are responsible for most bacterivory (Weisse 1999; Gasol et al. 2002). In thousands of years of coevolution, several bacterial strains have developed a number of strategies for surviving high grazing pressure by hetero- and mixotrophic nanoflagellates, and even to exploit the presence of these predators to gain advantages over other bacteria (anti-predation strategies are 
summarized by Matz \& Kjelleberg 2005). Moreover, some species generally known as "Winnie de Pooh"strategists (Thingstad et al.2005), are able to maximize nutrients uptake and predator defence simultaneously, getting a direct advantage by the presence of predators. All these anti-predator-strategists may use nutrients recycled by their predators in addition to those already available without high grazing pressure. The bacterial strains which are able to develop good predation resistance strategies generally are differently competitive in nutrient uptake (Corno 2006). Moreover the defence cost for most bacterial cells is generally considered high. It has been already shown that top-down factors have an impact not only on bacterial abundance and productivity but also on their relative diversity.

A common conclusion of theoretical models of microbial food-web interactions is that protistan predation is of minor importance for bacterioplankton community composition (Thingstad \& Lignell 1997; Thingstad 2000). By contrast, both experimental investigations and field studies suggest that deep shifts in the bacterial community composition can be promoted by raising the protistan predation (Pernthaler et al. 2001; Šimek et al. 2001).

To add new knowledge on the importance of topdown factors in shaping bacterial communities we designed an experiment in phosphorus-limited microcosms, considered as a proxy to natural oligotrophic conditions. We compared the relative impact of differential predation on abundance, biovolume, community composition and size-structure distribution of bacterial assemblages subject to grazing by different-sized predators. The relative diversity of microbial communities was estimated by a fingerprinting based approach for both prey and predators. Eukaryotic diversity was assessed by the T-RFLP (Terminal Restriction Fragment Length Polymorphism) fingerprinting technique, while bacterial diversity was determined using the ARISA (Automated Ribosomal Intergenic Spacer Analysis) technique. Redundancy Analyses (RDA) were used to test how much of the variance of independent variables (bacterial productivity, relative diversity, and predation pressure), explains the ecological success of the main bacterial operational taxonomic units (OTUs), the bacterial cell morphology distribution, and the success of eukaryotic OTUs.

\section{MATERIAL AND METHODS}

\subsection{Study site}

The experiment was performed in an artificial pond (dimensions $8 \times 12 \mathrm{~m}$, water depth $1.4 \mathrm{~m}$ ) directly connected to Lago Maggiore (Northern Italy), a deep (370 m) subalpine lake. A number of studies documented its trophic evolution in the last 50 years (e.g., Manca et al. 1992) and its present oligotrophic conditions after the restoration process (Salmaso et al. 2007). The pond presented a complex planktonic-microplanktonic commu- nity, closely related to the natural community of Lago Maggiore even if fishless. In Lago Maggiore large zooplankton (cladocerans and copepods, 10-20 ind $\mathrm{L}^{-1}$ ) and rotifers (principally Keratella spp. and Conochilus spp., $<25$ ind $\mathrm{L}^{-1}$ ) represent the main phytoplankton consumers (Manca et al. 2007). A number of ciliates (Oligotrichida, Scuticociliatida and Prostomatida, 2-50 $\times 10^{3}$ cil $\mathrm{L}^{-1}$ ) (Callieri et al. 2002; Callieri \& Heinimaa 1997), mixotrophic flagellates (principally the voracious Ochromonas sp., Chrysocromulina sp., Katablepharis sp., Uroglena sp., and Dinobryon spp.) (Morabito et al. 2007), and several small heterotrophic flagellates $(6.5 \times$ $10^{3}$ cell $\mathrm{mL}^{-1}$ ) (Callieri \& Heinimaa 1997) comprise the intermediate level (prey for the zooplankton but voracious predators of bacteria) of the system, while bacteria represent the bottom of the food chain. In June, the epilimnion of this lake typically has a seston C:N:P ratio of 80:12:1 and a Soluble Reactive Phosphorus (SRP) concentration of 3-7 $\mu \mathrm{g} \mathrm{L}^{-1}$ (for details, see Salmaso et al. 2003; Bertoni et al. 2004).

\subsection{Description of the microcosms and experimental conditions}

Forty cubic meters of water were pumped from a depth of 30 meters in the lake to the pond daily, allowing for a complete renewal of water every 3-4 days. On the first week of June 2005, water samples from the pond were collected from a depth of $0.5 \mathrm{~m}$, selectively filtered as described below, and finally used to fill 12 microcosms (volume 18 litres each), representing our experimental system (Fig. 1).

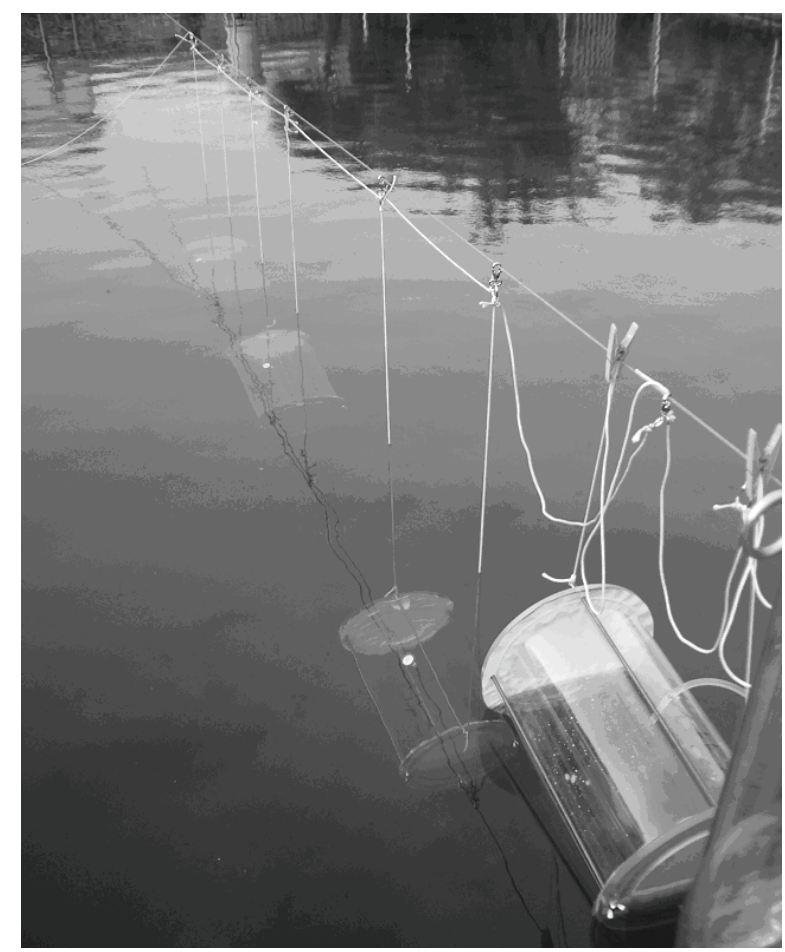

Fig. 1. Differential microcosms being placed into the artificial pond at the CNR-Institute of Ecosystem Study, in Verbania. 
Its scope was to allow the creation of modified communities in environments chemically and physically similar to the pond. The microcosms were transparent cylinders of polymethyl methacrylate (PMMA), $40 \mathrm{~cm}$ long and with a diameter of $24 \mathrm{~cm}$. They were closed at both ends with Sartorius acetate filters (pore size 0.2 $\mu \mathrm{m})$ that prevented exchange of microorganisms between microcosms and pond while permitting continuous water and nutrient exchange. To avoid the possible impact of confinement on natural communities incubated in artificial conditions (Massana et al. 2001), we planned microcosms made of plastic transparent to PAR (at $1 \mathrm{~m}$ depth UV radiation was almost non-existent), set up far from the bottom and the sides of the pond. Moreover, the microcosm was permeable to most inorganic nutrients and DOM through the two opposite large filters (pore size $0.2 \mu \mathrm{m}$ ). Since diffusion of dissolved nutrients in water is very slow (usually $<3 \mathrm{~mm} \mathrm{~h}^{-1}$ ) it could be possible to have partially reduced water exchange in the microcosms resulting in a potential lack of nutrients in their central part.

A preliminary comparison between test-microcosms filled with unfiltered water and samples from the pond was performed in order to evaluate the impact of potential nutrient limitation and biofilm formation in the microcosms: the further experimental design was based on the non-significance of the differences in bacterial abundances and biovolumes between the samples inside and outside the test-microcosms after 6 and 12 days (data not shown). Moreover, occasional comparison between Lago Maggiore and the pond were made during the experiment confirming the similarity of the water chemistry between lake and pond, and the state of oligotrophy of the system (in the pond, total phosphorus: $7 \mu \mathrm{g} \mathrm{L}^{-1}$; soluble reactive phosphorus: $1 \mu \mathrm{g} \mathrm{L}^{-1}$ ).

Consequently we considered data from the artificial pond as a natural control (NC). Microbial communities in the microcosms were modified through differential filtrations of pond water, at three levels of complexity: smaller than $0.7 \mu \mathrm{m}$ (filtration through Whatman GF/F filters, treatment NP), smaller than $10 \mu \mathrm{m}$ (treatment $10 \mathrm{P}$ ), and smaller than $50 \mu \mathrm{m}$ (treatment 50P). Each of the treatments was replicated four times. The cylinders were placed horizontally at $1 \mathrm{~m}$ below the water level, and suspended by using iron ropes fixed at the side of the artificial pond. Despite great care, a significant reduction in bacterial abundance was caused by filtration through GF/F filters (Treatment NP), as already demonstrated for natural bacterioplankton by a number of studies (Taguchi \& Laws 1988; Lee et al. 1995). Most affected were the largest cells, filamentous forms, and aggregates. Luckily, the relative community composition was less affected by the filtration, and none of the more prominent operational taxonomic unit (OTU) was removed.

Every third day for 12 days, the centre of each microcosm was sampled using a sterile syringe to with- draw $220 \mathrm{~mL}$ of water. At the same time, 4 samples $(220 \mathrm{~mL})$ of unfiltered water from the artificial pond were collected at $1 \mathrm{~m}$ depth and considered the natural control (treatment NC). $200 \mathrm{~mL}$ of sample were used for DNA extraction, 20 to other analyses.

\subsection{Microbial abundances, cell volumes, and grazing impact}

Samples were fixed with formaldehyde (final concentration, $2 \%$ ), stained with DAPI (final concentration, $0.1 \mu \mathrm{g} \mathrm{mL}^{-1}$ ), filtered onto $0.2 \mu \mathrm{m}$ pore-size polycarbonate filters, and counted by epifluorescence microscopy. At least 400 bacteria and 100 predators (small protists) were counted per sample. Cellular biovolumes were taken from DAPI-stained samples using an automated image analysis system (Image-Pro Plus 5.1, Media Cybernetics), and calculated according to the algorithms proposed by Massana and co-workers (1997). An indirect estimation of the bacterial production (BB) was made by measuring the increment from date to date of the net bacterial biovolume (Kirchman et al. 1982).

Bacterial cells longer than $5 \mu \mathrm{m}$ (here reported as Filaments) and bacterial aggregates composed of more than 10 cells (here reported as Aggregates) were assumed to be inedible for most of bacterivorous nanoflagellates (Šimek et al. 1997; Hahn \& Höfle 2001; Corno 2006). Cells shorter than these dimensions but with a total biovolume $>0.1 \mu \mathrm{m}^{3}$ were considered edible (here reported as Edible cells). The smallest free living cells, with cell volume $<0.07 \mu \mathrm{m}^{3}$, are commonly identified as ultramicrobacteria (Boenigk \& Arndt 2002; Boenigk et al. 2004) (here reported as Small cells) and are considered very resistant to most predation (Sherr et al. 1992).

We used the mean prey-predator ratio to evaluate grazing pressure. This is basically the chance of a single prey encountering a predator. For this calculation, we equated prey with our edible bacteria (defined above) and predators with protists. The size of prey particles was taken into account for the calculation accordingly with the model proposed by Shimeta \& Jumars (1991), without considering the potential motility of some prey cells.

\subsection{DNA extraction and $P C R$}

Two hundred $\mathrm{ml}$ of each treatment replicate (collected at day $0,6,9,12$ ) were filtered on 25-mm Supor filters (pore size $0.2 \mu \mathrm{m}$ ) and stored in $1.5 \mathrm{ml}$ lysis buffer at $-20^{\circ} \mathrm{C}$. Nucleic acid extraction was performed directly from the filters using the UltraClean Soil Kit (Mobio Laboratories Inc., California). DNA integrity was checked by agarose gel electrophoresis, and DNA yield was quantified by a Hoechst dye fluorescence assay (Paul \& Myers 1982). Nucleic acid extracts were stored at $-80^{\circ} \mathrm{C}$ until analysis. 
About 2 ng of extracted DNA were used as template for different PCRs. Terminal restriction fragment length polymorphism (T-RFLP) on the eukaryotic $18 \mathrm{~S}$ rDNA gene (Massana \& Jürgens 2003) was used for the analysis of predator diversity, while automated ribosomal intergenic spacer analysis (ARISA), which amplifies the ITS1 region in the rRNA operon plus a small part of $16 \mathrm{~S}$ and 23S rRNA, was used for evaluation of bacterial diversity. The latter allows better resolution of bacterial community composition (Hewson \& Fuhrman 2004; Danovaro et al. 2006), being based on amplification of the ITS1 region (the intergenic region between the $16 \mathrm{~S}$ and $23 \mathrm{~S}$ rRNA genes in the rRNA operon), which is characterized by high variability in length and nucleotide sequence among bacterial genotypes (Fisher \& Triplett 1999). Moreover, an accurate choice of the primers reduced the mistakes due to amplification problems reported for many of the available primers on gene 23S rRNA (Hunt et al. 2006). This was the first application of this method in freshwater microcosms.

For T-RFLP amplifications, primers Euk1F (5'labelled with FAM) and Euk516R were used. The PCR mixtures $(50 \mu \mathrm{L})$ contained forward and reverse primers (each at $0.3 \mu \mathrm{M}$ ) and $20 \mu \mathrm{L}$ of PCR Master Mix (Promega). The PCR amplification program consisted of an initial denaturation step at $94{ }^{\circ} \mathrm{C}$ for $2 \mathrm{~min}$, followed by 3030 -s cycles of denaturation at $94{ }^{\circ} \mathrm{C}$, annealing at $56{ }^{\circ} \mathrm{C}$ for $45 \mathrm{~s}$ and extension at $72{ }^{\circ} \mathrm{C}$ for 2 min. During the last cycle, the extension step was increased to $7 \mathrm{~min}$. Amplicons were checked by electrophoresis of $4 \mu \mathrm{L}$ of the PCR product in a $0.8 \%$ agarose gel stained with ethidium bromide.

For ARISAs, extracted DNA was amplified using universal bacterial primers $16 \mathrm{~S}-1392 \mathrm{~F}$ and $23 \mathrm{~S}-125 \mathrm{R}$ (labelled with HEX) (Hewson \& Fuhrman 2004). PCRs were performed in a volume of $50 \mu \mathrm{L}$ containing forward and reverse primers (each at $0.3 \mu \mathrm{M}$ ) and $20 \mu \mathrm{L}$ of PCR Master Mix (Promega). PCR program consisted of 3 min of denaturation at $94{ }^{\circ} \mathrm{C}$ followed by thirty cycles of $94{ }^{\circ} \mathrm{C}$ for $1 \mathrm{~min}, 55{ }^{\circ} \mathrm{C}$ for $1 \mathrm{~min}$, and $72{ }^{\circ} \mathrm{C}$ for 2 $\mathrm{min}$, and by a final extension of $10 \mathrm{~min}$ at $72{ }^{\circ} \mathrm{C}$. The quality of amplified fragments was checked using the same electrophoresis done for T-RFLP amplicons. TRFLP and ARISA fluorescently labelled PCR products were purified using a PCR purification kit (Qiagen).

\subsection{T-RFLP and ARISA}

T-RFLP procedures were those of Massana \& Jürgens (2003), with slight modifications. Purified FAM-labelled PCR products were digested overnight with restriction enzymes at $37{ }^{\circ} \mathrm{C}$. Each digested product contained $4 \mu \mathrm{L}$ PCR product, $5 \mathrm{U}$ of the restriction enzymes Msp I (Promega) and the recommended buffer. Just before loading onto the sequencer, $3 \mu \mathrm{L}$ of restriction digest was denatured at $94{ }^{\circ} \mathrm{C}$ for $2 \mathrm{~min}$ in the presence of $2.5 \mu \mathrm{L}$ of deionized formamide and $0.5 \mu \mathrm{L}$ of internal size standard, and immediately chilled on ice.
Terminal restriction fragments (TRFs) were separated and detected by electrophoresis at $2800 \mathrm{~V}$ for $7 \mathrm{~h}$ in a denaturing 5\% acrylamide gel with an ABI Prism 377 automated sequencer. The sizes of the TRFs, which represent different operational taxonomic units (OTUs), were determined by comparing them with the internal size standard ROX 1000 (Applied Biosystems) using the local southern size-calling method of the software GeneScan 3.1 (Applied Biosystems). We did not include TRFs that appeared less than $1.9 \mathrm{bp}$ from larger ones (commonly called "shoulder peaks") or that were not present in at least two samples (irreproducible peaks considered as PCR artefacts). The detection threshold was set to be $0.20 \%$ of the total fluorescence (as proposed by Luna et al. 2006).

The relative abundance of each significant TRF within a sample was determined by calculating the ratio of its peak height to the total peak height of all TRFs within the sample (Osborn et al. 2000).

For ARISA fingerprinting detection, the purified HEX-labelled PCR products were denatured $(3 \mu \mathrm{L}$ of PCR product, $2.5 \mu \mathrm{L}$ of deionized formamide and 0.5 $\mu \mathrm{L}$ of internal size standard; ROX 1000, Applied Biosystems) at $94{ }^{\circ} \mathrm{C}$ for $2 \mathrm{~min}$, then chilled on ice, and carried in the sequencer for the analysis. Detection of ARISA fragments and discrimination between peaks was accomplished with the same sequencer operating under the same conditions described above. Again, the same methodology was used for the discrimination between peaks, for ARISA, and for T-RFLP representing different OTUs, depending on their bp sizes. The Shannon diversity index $(H)$ was calculated by using single peaks as OTUs and the standardized peak heights as relative abundance. The proportion $\left(p_{i}\right)$ of the OTU $i$ relative to the total value of OTUs peak heights is calculated, and then multiplied by the natural logarithm of this proportion $\left(\ln p_{i}\right)$. The resulting product is summed across OTUs (total OTU number, $s$ ), and multiplied by -1 :

$$
H=-\sum_{i=1}^{s}\left(p_{i} \ln p_{i}\right)
$$

\subsection{Statistics}

Analyses of variance (Repeated Measurements (RM) Anova, Tukey tested) and paired t-tests (Bonferroni corrected) were performed in order to test for differences between temporal series and pairs of treatments, respectively. A difference was considered as significant when $\mathrm{P}$ was $<0.05$. Statistical analyses were carried out with SigmaStat 3.5 (Systat Software Inc.). Furthermore redundancy analysis (RDA) was used to test the relation between single bacterial OTUs (dependent variables) and bacterial production (BB) (measured as net increment in bacterial biovolume), predation pressure (PP), and relative bacterial (BD) and eukaryotic (ED) community diversity (independent variables) as suggested by Ramette (2007). The same analysis was performed to evaluate the relative importance of single eukaryotic 
and bacterial OTUs and to link it to peculiar cell morphologies (as previously defined). All data were squareroot transformed before being processed and further computed with Canoco 4.5 (ter Braak \& Smilauer 1998).

\section{RESULTS}

In order to assess the relative grazing pressure on the bacterial communities, the relation between the number of edible bacterial cells and the number of protistan predators for each treatments, was calculated considering the relative size of the prey (Fig. 2). Starting from day 6 in treatment 10P and from day 9 in treatment 50P the predation pressure on the edible portion of the bacterial communities in the treatments was higher than in the natural control (NC).

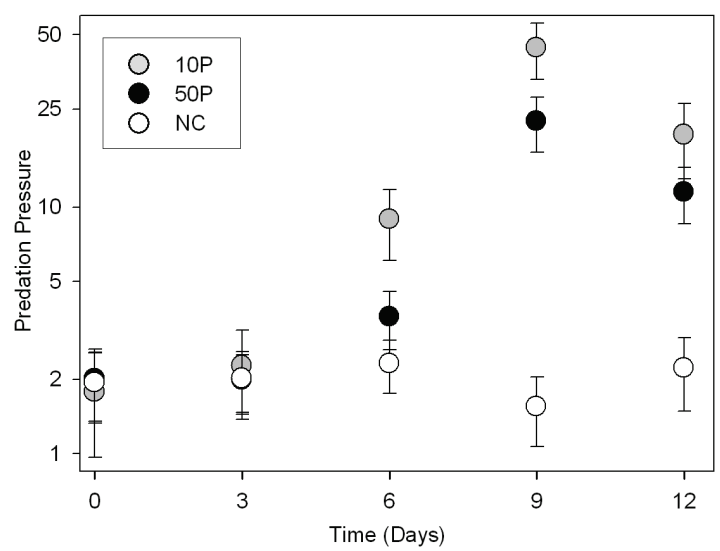

Fig. 2. Predation pressure on the edible portion of bacterial assemblages, measured as risk for a bacterium of encountering a protist as described in the M\&M chapter (means of four replicates \pm s.d.). Data measured for treatments 10P (grey circles), 50P (black circles) and for the natural control (NC, white circles). NP treatment was predators free.

\subsection{Microbial abundances and biovolumes}

Bacterial abundance was very stable in the natural control (NC) over the 12-day experiment, ranging between 2.30 and $2.56 \times 10^{6}$ cell $\mathrm{mL}^{-1}$ (Fig. 3, black squares). Filtration to create the NP (no predator) treatment removed some bacteria, but numbers remained relatively stable thereafter, ranging between 1.44 and $1.61 \times 10^{6}$ cell $\mathrm{mL}^{-1}(\mathrm{P}=0.993$ for $\mathrm{NP}, \mathrm{P}=0.085$ for $\mathrm{NC}$ and $\mathrm{P}<0.001$ for the comparison NP vs NC; RM Anova, Tukey tested). By contrast, the two treatments with manipulated populations of predators started out with bacterial numbers similar to outside the microcosms but experienced decreases over time (after 6 days in $10 \mathrm{P}$ and after 9 days in 50P). At day 12, bacterial abundances were reduced to $1.34 \pm 0.31 \times 10^{6}$ cell mL $^{-1}$ in $50 \mathrm{P}$ and $0.95 \pm 0.28 \times 10^{6}$ cell $\mathrm{mL}^{-1}$ in $10 \mathrm{P}$.

Bacterial biovolume dynamics (Fig. 3, white squares) followed trends closely parallel to those for abundance in the natural control (NC) and the 10P and
$50 \mathrm{P}$ treatments. Initially, mean bacterial biovolume ranged from $0.36-0.44 \times 10^{6} \mu \mathrm{m}^{3} \mathrm{~mL}^{-1}$. The natural control maintained this biovolume, over the study, its day 12 value being $0.46 \pm 0.17 \times 10^{6} \mu \mathrm{m}^{3} \mathrm{~mL}^{-1}$, while $10 \mathrm{P}$ and $50 \mathrm{P}$ decreased biovolume. Their biovolumes on day 12 were $0.17 \pm 0.05 \times 10^{6} \mu \mathrm{m}^{3} \mathrm{~mL}^{-1}$ and $0.20 \pm 0.05$ $\times 10^{6} \mu \mathrm{m}^{3} \mathrm{~mL}^{-1}$, respectively. Total bacterial biovolume dynamics were different in the treatment without predators (NP, $\mathrm{P}=0.002$, RM Anova, Tukey tested). Here biovolume rose constantly, from an initial value of $0.14 \pm 0.06 \times 10^{6} \mu \mathrm{m}^{3} \mathrm{~mL}^{-1}$ to $0.30 \pm 0.13 \times 10^{6} \mu \mathrm{m}^{3}$ $\mathrm{mL}^{-1}$ on day 12 .

\subsection{Predator abundances and diversity}

Protistan predator abundance (Fig. 4A) remained constant in NC during the 12 days of the experiment, ranging between 1.71 and $2.19 \times 10^{3}$ cell $\mathrm{mL}^{-1}(\mathrm{P}=$ 0.081 ). At time 0 , the protistan predator abundances in $10 \mathrm{P}$ and 50P treatments were similar to the abundance in the natural environment but then, starting with day 6 in 10P and day 9 in 50P, predators increased. Maximum densities were reached on day 9 , with $7.05 \pm 0.96 \times 10^{3}$ cell $\mathrm{mL}^{-1}$ and $5.24 \pm 0.57 \times 10^{6}$ cell $\mathrm{mL}^{-1}$, in treatments $10 \mathrm{P}$ and 50P respectively. Densities then decreased to $<4 \times 10^{3}$ cells $\mathrm{mL}^{-1}$ on day 12 .

Shannon diversity was measured for small eukaryotes as well, using data obtained by T-RFLP analysis (Fig. 4B). Natural communities were maintained in the control treatment during the 12 days of experimentation $(\mathrm{P}=0.638)$. By contrast, eukaryotic diversity decreased where predation was reduced (more in 10P than 50P).

\subsection{Size-structure of bacterial communities}

Variations in the mean bacterial cell size (characterized by high standard deviation due to the presence of very different bacterial morphotypes) were observed both across treatments and over time. Bacterial sizes remained quite constant in $\mathrm{NC}$ samples, with the average cell biovolume ranging between $0.16 \pm 0.06$ and $0.19 \pm 0.15 \mu^{3}$ cell $^{-1}$. The treatments with elevated protistan predation (10P) was characterised by an increment in average bacterial cell size. Conversely, cell size in treatment 50P reduced, although, for both $10 \mathrm{P}$ and $50 \mathrm{P}$, there was not a clear incrementing/reducing trend but oscillations over time (data not shown). The initial mean size of $0.17 \pm 0.14 \mu^{3}$ cell $^{-1}$,common for

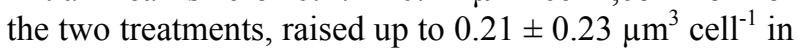
$10 \mathrm{P}$, while in 50P dropped below $0.12 \pm 0.17 \mu^{3}$ cell $^{-1}$. In treatment NP, the mean bacterial size increased constantly, rising from $0.09 \pm 0.06 \mu^{3}$ cell $^{-1}$ to $0.20 \pm 0.11$ $\mu \mathrm{m}^{3}$ cell $^{-1}$ at the end of the experiment. This increment, although not significant for the presence of different size-class bacteria, was realistic as the total bacterial biovolume in this treatment increased significantly (ttest, $\mathrm{P}<0.01$ ) while the number of bacteria remained constant. 


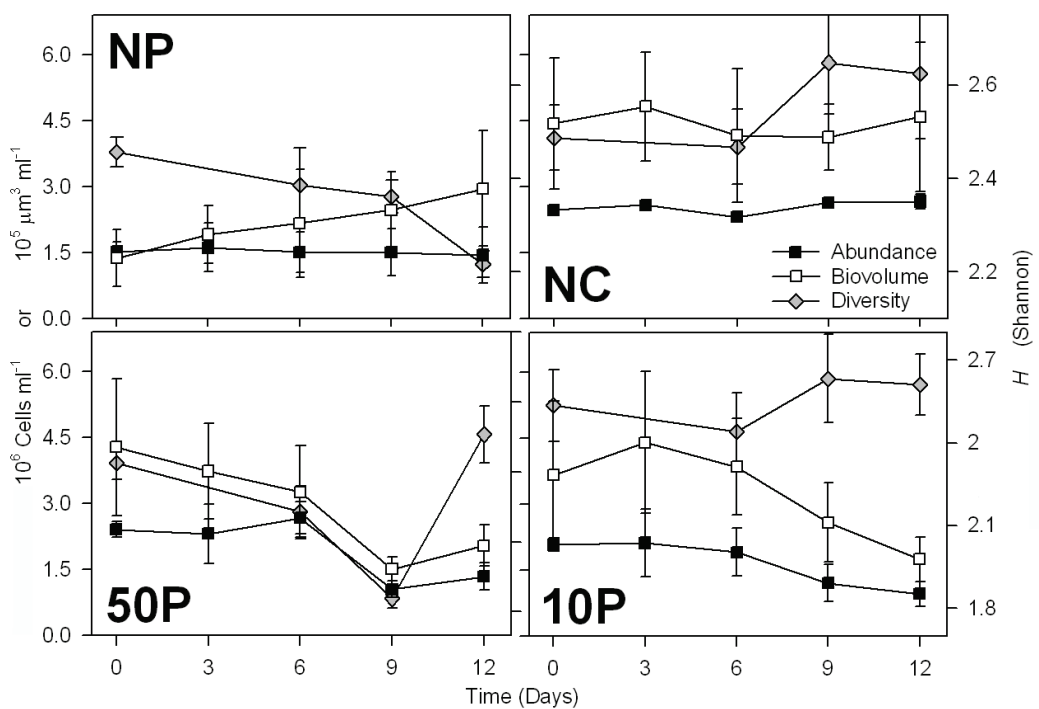

Fig. 3. General dynamics of bacterial communities in different treatments and in the natural control (NC). Black squares refer to bacterial abundance, white ones to community biovolume and grey diamonds to bacterial diversity (measured as Shannon Index on OTUs). Left axes refer to bacterial number and biovolume, while right ones to bacterial diversity. All values are means of four replicates $( \pm$ s.d. $)$.

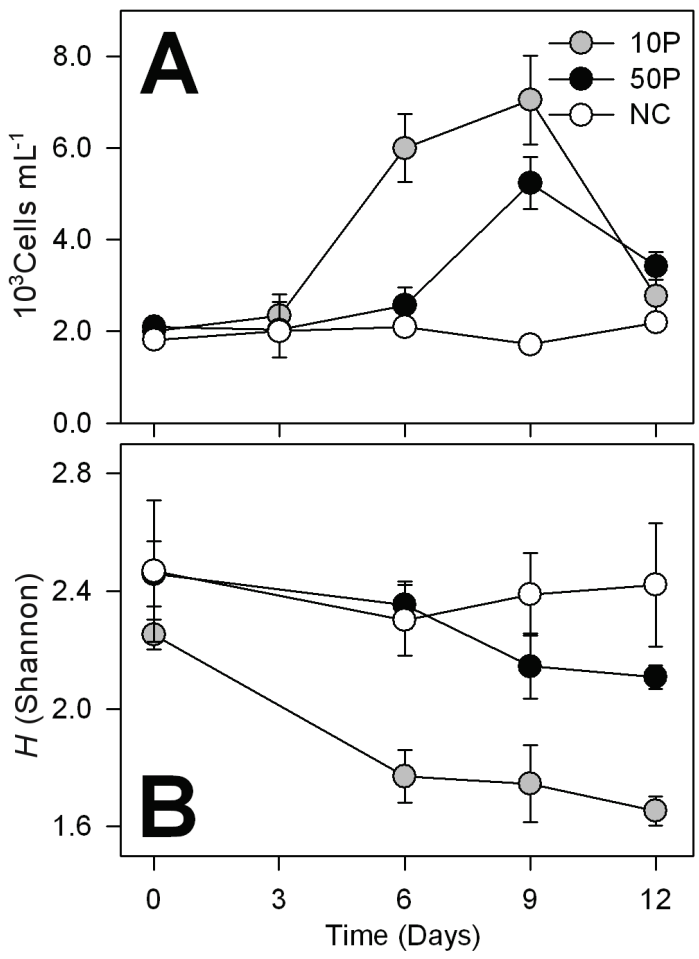

Fig. 4. Overall abundance (graph A) and diversity (graph B, measured as the Shannon Index, $\mathrm{H})$ of protists $(<10 \mu \mathrm{m})$ in treatment 10P (grey circles), 50P (black circles) and in the natural control (NC, white circles). All values are means of four replicates ( \pm s.d.).

The natural control (NC) community was composed mainly of free-living bacteria (Edible cells $38-44 \%$ of the total number, Small cells 50-55\%) with lesser amounts of Filaments and large Aggregates (if counted together they ranged between $5-8 \%$ of the total number) (Fig. 5, abundances). Treatment NP led to the development of a substantial number of Edible cells. These accounted for $38 \%$ of total bacteria at the beginning of the experiment and $67 \%$ at the end. Coupled to their success, a constant and parallel reduction of Small cells was noticed (dropped from more than $60 \%$ on day 0 , to $30 \%$ on day 12). In NP, Aggregates and Filaments together never exceeded $4 \%$ of the total number. In $10 \mathrm{P}$ and $50 \mathrm{P}$, the number of Edible cells dropped dramatically over the course of the study, from about $50 \%$ (day 0 ) in both treatments, to $35 \%$ in $50 \mathrm{P}$ and about $20 \%$ in 10P. Also in contrast with NP, Small cells remained a nearly constant proportion of total bacteria over the experiment in these treatments $(34-42 \%$ in $10 \mathrm{P}$ and $43-$ $50 \%$ in $50 \mathrm{P}$ ). The vacancy of medium sized Edible cells was filled by increased presence of highly predator-resistant shapes, including Filaments (increased from $<3 \%$ at time 0 to $18 \%$ in $10 \mathrm{P}$, and to $11 \%$ in $50 \mathrm{P}$ ) and Aggregates (from $<3 \%$ to $26 \%$ in $10 \mathrm{P}$, and to $13 \%$ in $50 \mathrm{P}$ ).

In terms of biovolume (Fig. 5, biovolumes), most of the already described trends resulted emphasized. Edible cells proportion accounted constantly between 48$57 \%$ in NC, while it rose almost up to $80 \%$ in NP and resulted reduced to about $20 \%$ under enhanced grazing pressure (10P and 50P). Small cells kept constant in $\mathrm{NC}, 10 \mathrm{P}$, and $50 \mathrm{P}$ accounting for about 30,15 , and $20 \%$ respectively, for the whole experiment. In treatment NP Small cells proportion reduced from $42 \%$ at day 0 to $16 \%$ at day 12. In the same treatment, Aggregates and Filaments together never exceeded $10 \%$ of the total biovolume. Their relative importance dramatically rose in $10 \mathrm{P}$ and $50 \mathrm{P}$ where, starting from relatively reduced proportions (in total about $20 \%$ for both treatments), at 


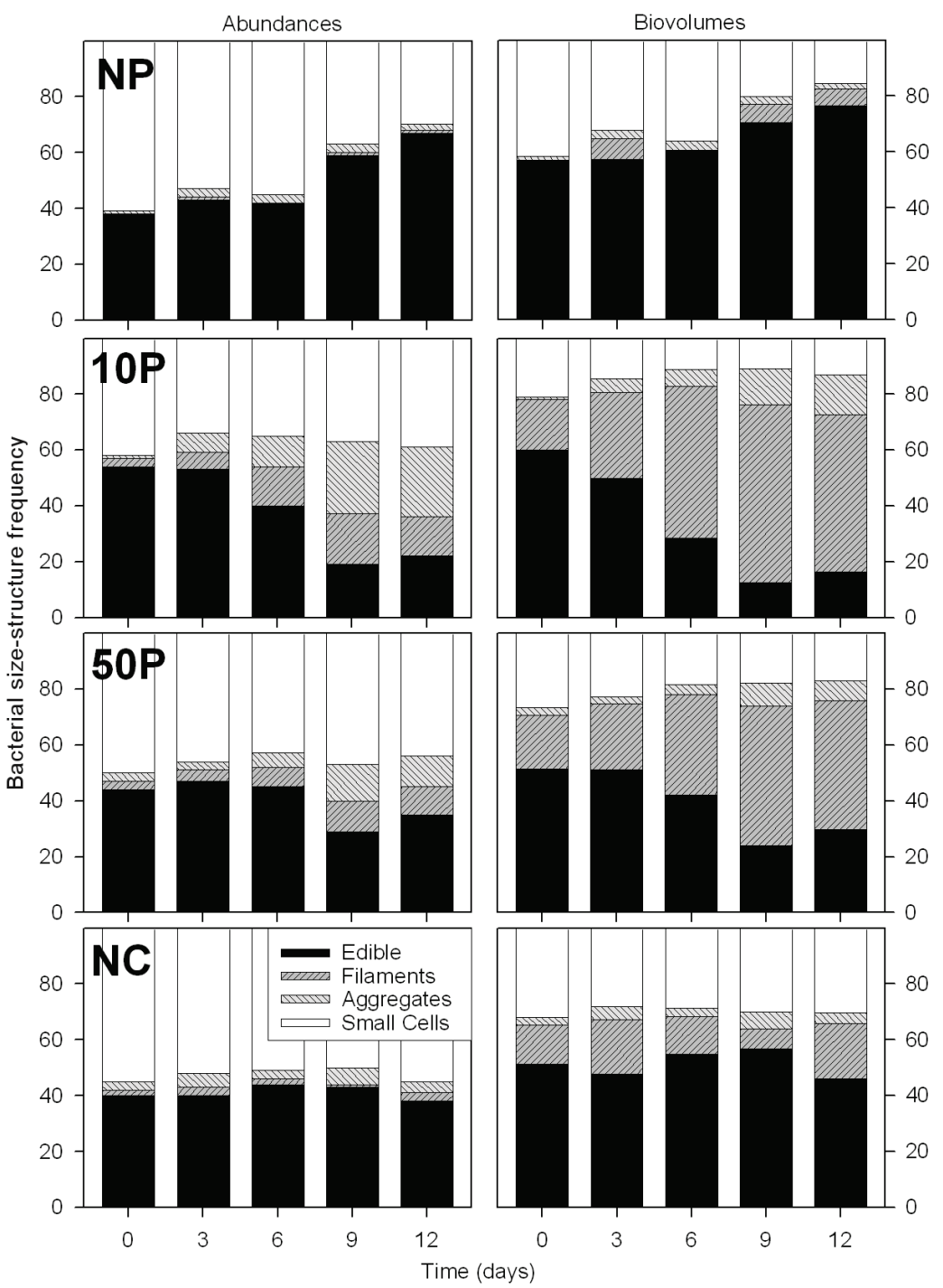

Fig. 5. Size-structure distribution of bacterial assemblages depicted on cell abundance (left column) or related biovolume (right column) as Edible (black bars), or inedible for most of the predators (striped for Filaments and Aggregates, white for Small Cells). All values are means of four replicates.

day 12 they dominate the biovolume of the community accounting for $77 \%$ (64\% Filaments) and 58\% (50\% Filaments) in $10 \mathrm{P}$ and $50 \mathrm{P}$, respectively.

\subsection{Microbial community composition and diversity}

Using the ARISA technique, we compared the relative bacterial diversity in all treatments at day $0,6,9$, and 12. A treatment effect was apparent both when sample diversity was measured as number of significant peaks (each correspondent to a single OTU), and when relative peak weight was taken into account (Shannon diversity, Fig. 3, grey squares). The number of significant OTUs counted in each sample ranged from 22 and 43 , with trends similar to the Shannon diversity measured with the Shannon Index. At the beginning of the experiment, bacterial diversity $(H)$ was rather similar in all 12 systems, as well as in the natural control (range $H$
$=2.45$ and 2.53). $\mathrm{NC}$ largely maintained this diversity (for $H$ at time 0 versus time 12, $\mathrm{P}=0.063$, $\mathrm{RM}$ Anova Tukey tested), while bacterial diversity in the NP treatment was steadily reduced over the 12 days, ending at 2.21 ( $<<0.001)$ (Fig. 3). In the 10P treatment, Shannon bacterial diversity was maintained $(H=2.61$ on day 12 , $\mathrm{P}=0.236$ ) despite a huge drop in bacterial abundance and biomass (inversely correlated with the numbers and biomass of predators). Large oscillations in bacterial diversity characterized the $50 \mathrm{P}$ treatment; it was impossible to define a clear trend over time.

Fourteen bacterial OTUs were predominant in most of the bacterial communities; altogether, they comprised at least $65 \%$ of the total peak height of each sample (Tab. 1). The different treatments clearly modified OTU distribution, which was similar across treatments initially. OTU 397 was maintained at similar levels (18- 
Tab. 1. Relative weight of the 14 main bacterial operational taxonomic units (OTUs) and of the 12 main eukaryotic OTUs in the system. Total weight of the selected OTUs on the total diversity is summarized, for each date and for each treatment in the last row. Data are shown for the beginning ( 0 day), the middle ( 6 day) and the end (12 day) of the experiment. Weighted trends of single OTU's relative importance in the community are listed for each OTU in each treatment. All values are means of the four treatment replicates. $(\mathrm{NC}=$ Natural Community; $\mathrm{NP}=\mathrm{No}$ Predation; $10 \mathrm{P}=$ filtered $10 \mu \mathrm{m} ; 50 \mathrm{P}=$ filtered $50 \mu \mathrm{m})$.

\begin{tabular}{|c|c|c|c|c|c|c|c|c|c|c|c|c|c|c|c|c|c|}
\hline \multirow{2}{*}{\multicolumn{2}{|c|}{$\begin{array}{c}\text { Treatment } \\
\text { Day }\end{array}$}} & \multicolumn{4}{|c|}{$\mathrm{NC}$} & \multicolumn{4}{|c|}{ NP } & \multicolumn{4}{|c|}{$10 \mathrm{P}$} & \multicolumn{4}{|c|}{$50 \mathrm{P}$} \\
\hline & & 0 & 6 & 12 & Trend & 0 & 6 & 12 & Trend & 0 & 6 & 12 & Trend & 0 & 6 & 12 & Trend \\
\hline \multirow{15}{*}{ 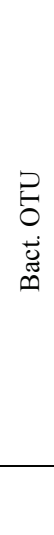 } & 397 & 19.8 & 19.2 & 19.1 & $=$ & 17.0 & 16.8 & 17.1 & $=$ & 17.5 & 9.4 & 7.9 & $\nabla$ & 18.2 & 15.1 & 20.7 & $=$ \\
\hline & 500 & - & - & 1.0 & - & - & - & - & - & - & 6.5 & 3.3 & - & - & 0.9 & - & - \\
\hline & 567 & 1.1 & 1.3 & 1.9 & $\Delta$ & 4.9 & - & 3.8 & - & 1.9 & 2.2 & 1.1 & $=$ & 1.4 & 1.6 & 1.5 & $=$ \\
\hline & 571 & 4.3 & 2.9 & - & $\nabla$ & - & - & - & - & 4.4 & 1.3 & - & $\nabla$ & 2.8 & 3.0 & 2.8 & $=$ \\
\hline & 581 & 3.1 & 1.0 & 2.9 & $=$ & 14.2 & 8.7 & 2.8 & $\nabla$ & 5.7 & 11.0 & 19.0 & $\mathbf{\Delta}$ & 2.8 & 1.7 & 1.0 & $\nabla$ \\
\hline & 595 & 3.3 & 4.5 & 7.3 & $\Delta$ & 11.9 & 7.0 & 11.4 & $=$ & 5.7 & 1.9 & - & $\nabla$ & 3.3 & 5.4 & 3.0 & $=$ \\
\hline & 643 & 20.2 & 20.3 & 8.3 & $\nabla$ & 4.1 & 7.7 & 9.4 & $\Delta$ & 21.1 & 4.5 & - & $\nabla$ & 14.9 & 14.9 & 16.4 & $=$ \\
\hline & 654 & 3.1 & 7.3 & 10.9 & $\Delta$ & 6.5 & 2.4 & 11.8 & $\Delta$ & 4.8 & 4.8 & 6.1 & $=$ & 1.3 & 2.0 & 5.6 & $\Delta$ \\
\hline & 730 & - & 4.6 & 0.9 & - & 10.3 & 10.3 & 5.5 & $\nabla$ & - & - & - & - & 17.7 & 5.9 & - & $\nabla$ \\
\hline & 815 & 1.9 & 1.9 & 2.1 & $=$ & 2.8 & 1.5 & 2.7 & $=$ & 2.3 & 5.3 & 15.5 & $\Delta$ & 1.5 & 2.3 & 2.9 & $\Delta$ \\
\hline & 829 & 1.1 & 3.4 & 2.0 & - & - & 5.5 & 12.4 & $\Delta$ & 1.1 & 4.1 & 7.5 & $\mathbf{\Delta}$ & 0.9 & 2.5 & 2.7 & $\Delta$ \\
\hline & 850 & 2.4 & 2.8 & 1.8 & $=$ & 2.2 & 1.9 & 2.0 & $=$ & 3.1 & 2.2 & - & $\nabla$ & 1.5 & 2.9 & 2.3 & $=$ \\
\hline & 874 & 2.3 & 3.1 & 1.9 & $=$ & 1.4 & 2.5 & 9.4 & $\Delta$ & 3.3 & 8.6 & 18.5 & $\mathbf{\Delta}$ & 1.4 & 1.7 & 3.9 & $\boldsymbol{\Delta}$ \\
\hline & \multirow[t]{2}{*}{894} & 2.4 & 5.7 & 7.9 & $\Delta$ & 5.6 & 1.7 & 7.3 & $=$ & 3.7 & 4.9 & 16.0 & $\Delta$ & 3.6 & 6.7 & 10.7 & $\Delta$ \\
\hline & & 65.1 & 78.0 & 67.9 & & 81.0 & 66.2 & 95.6 & & 74.6 & 66.7 & 95.1 & & 71.2 & 66.6 & 73.4 & \\
\hline \multirow{13}{*}{ 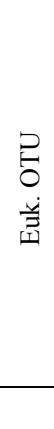 } & 59 & 14.1 & 15.7 & 15.1 & $=$ & - & - & - & - & 16.6 & 22.2 & 26.7 & $\Delta$ & 14.0 & 18.6 & 23.3 & $\Delta$ \\
\hline & 67 & 17.63 & - & - & $\nabla$ & - & - & - & - & 15.9 & 22.5 & - & $\nabla$ & 12.7 & - & - & $\nabla$ \\
\hline & 71 & - & 11.4 & 14.0 & $\Delta$ & - & - & - & - & 4.7 & - & 21.2 & $\Delta$ & 3.4 & 18.1 & 22.7 & $\Delta$ \\
\hline & 88 & 14.5 & 14.6 & 11.0 & $\nabla$ & - & - & - & - & 12.8 & 15.9 & 19.9 & $\Delta$ & 10.2 & 14.1 & 22.5 & $\Delta$ \\
\hline & 235 & 4.8 & 2.1 & 7.5 & $=$ & - & - & - & - & - & - & - & - & 1.8 & 3.2 & - & - \\
\hline & 238 & 7.3 & 6.6 & 2.0 & $\nabla$ & - & - & - & - & 9.9 & - & - & $\nabla$ & 10.6 & - & - & $\nabla$ \\
\hline & 285 & 1.6 & 2.9 & 3.7 & $\Delta$ & - & - & - & - & 13.0 & 1.1 & 2.1 & $\Delta$ & 4.7 & 14.8 & 2.9 & $=$ \\
\hline & 287 & 7.0 & 2.2 & - & $\nabla$ & - & - & - & - & 8.4 & 5.3 & - & $\nabla$ & - & - & - & - \\
\hline & 370 & - & 1.4 & 2.9 & $\boldsymbol{\Delta}$ & - & - & - & - & 1.9 & 3.7 & 1.8 & $=$ & 4.4 & - & - & $\nabla$ \\
\hline & 378 & 2.4 & 5.7 & 9.1 & $\Delta$ & - & - & - & - & - & - & 2.8 & - & 6.8 & 5.4 & - & $\nabla$ \\
\hline & 380 & 2.3 & 3.7 & 5.8 & $\Delta$ & - & - & - & - & - & 12.4 & 14.7 & $\Delta$ & 11.2 & 4.9 & 8.4 & $=$ \\
\hline & \multirow[t]{2}{*}{382} & 11.2 & 12.7 & 14.0 & $=$ & - & - & - & - & 8.9 & 9.6 & - & - & 13.9 & 6.5 & 6.8 & $\nabla$ \\
\hline & & 82.8 & 79.0 & 85.1 & & - & - & - & - & 92.1 & 92.7 & 89.2 & - & 93.7 & 85.6 & 86.6 & \\
\hline
\end{tabular}

$20 \%)$ in all treatments over the entire experiment, with the exception of a decline to $8 \%$ in treatment $10 \mathrm{P}$ on days 6 and 12. OTU 643 was generally abundant at the beginning of the experiment but decreased in the natural control $(\mathrm{NC}$ ) and in 10P (at day 12 it reached $8.3 \%$ in $\mathrm{NC}$, while it completely disappeared in 10P), and increased in NP (from 4.1 to $9.4 \%$ ). It remained stable around $15 \%$ in 50P however. A clear selection against OTUs 581 and 730 was evident in treatment NP where the importance of OTUs 643, 654, 829 and 874 increased. Under high predation pressure by small protists (treatment 10P), OTU 571, 595, 643 and (partly) 850 disappeared after 6 days, whereas OTUs 581, 815, 829,874 and 894 increased in relative importance. Finally, in treatment $50 \mathrm{P}$ it is interesting to note that OTUs $815,829,874$ and 894 increased less profoundly as they did in 10P, while OTU 730 decreased significantly. OTU 730 was dominant only in treatment NP, where it also declined over time. It was absent in 10P and low in NC.

A redundancy analysis (RDA, Fig. 6A) was performed in order to evaluate the relationships between the presence, and the relative importance, of the main bacterial OTUs (Tab. 1) and the overall predation pressure (PP), the bacterial production (BB) and the diversity of the bacterial community (BD). With correlation matrix scores of 0.97 and 0.13 (on axes 1 and 2, respectively) for PP, -0.63 and 0.00 for BB, and 0.72 and 0.25 for $\mathrm{BD}$, it is demonstrated a positive correlation between axis 1 and grazing pressure and diversity of the bacterial community, and a negative correlation with the apparent increment of bacterial biovolume. Moreover from this analysis it is possible to identify two groups of bacterial OTUs (Fig. 6A), one favoured by low (or null) grazing pressure (group 1) and composed mainly by Small cells and Edible cells, and one stimulated by the activity of the predators (group 2) and formed by Filaments and Aggregates. Only two of the dominant OTUs (829 and 571) did not seem to be affected by the selected environmental variables. Plotting eukaryotic OTUs with PP, BD and relative eukaryotic diversity (ED) (Fig. 6B) it appears a negative correlation between PP (scores 0.96 and -0.29 ) and axis 1 , and between BD (0.13 and -0.99$)$ and axis 2 , while ED (0.85 and 0.52) appear as slightly positively correlated with axis 1 . With elevated grazing activity a group of OTUs appear 

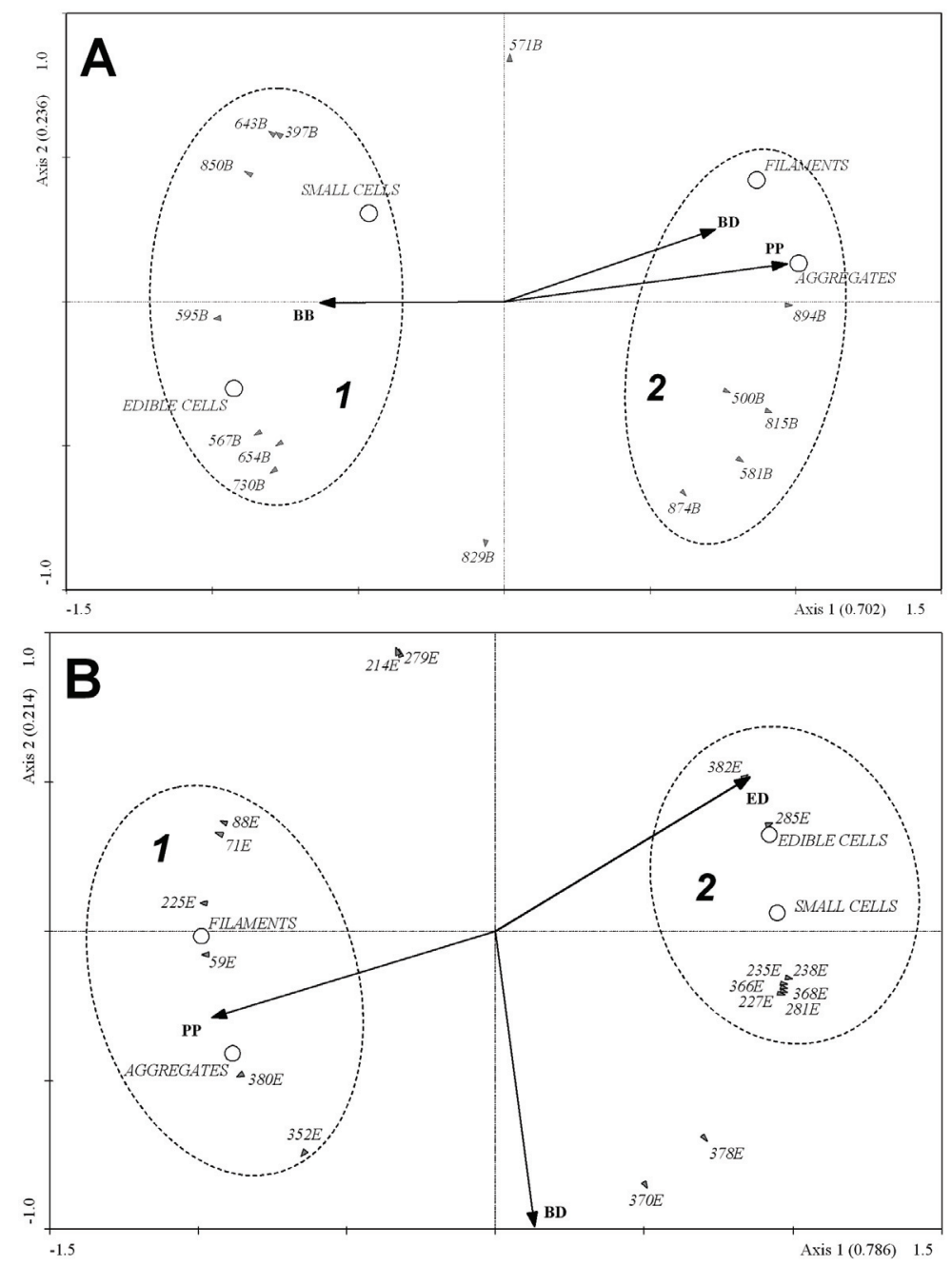

Fig. 6. RDA-ordination biplot of the 14 main bacterial OTUs from table 1 and environmental variables (graph A), and of 10 of the main eukaryotic OTUs (from table 1) plus 8 occasional eukaryotic OTUs (useful for the analysis) and environmental variables (graph B). Size-structure classes of bacteria are analyzed and plotted in the graph as species as well (named Small Cells, Edible cells, Filaments, and Aggregates following the definition given in the Methods). All species are represented by grey arrow heads but for clarity the only tips were drawn for species defined by OTUs, while an empty circle identify species defined by size-structure classes of bacteria. The environmental variables are represented by black lined arrows and correspond to the net increment of bacterial communities biovolume (BB), the predation pressure (PP) and the relative diversity of the bacterial communities (BD) in graph A; and by $\mathrm{PP}, \mathrm{BD}$ and relative diversity of the eukaryotic communities (ED) in graph B. Arrows with narrow angles are strongly correlated, arrows that are perpendicular show no correlation and arrows in opposite directions indicate negative correlation.

favoured (Fig. 6B, group 1), while a second group of OTUs appear as successful with low grazing activity, promoting the increment of the eukaryotic diversity.

\section{DISCUSSION}

\subsection{Microbial dynamics at different predation level}

The natural control (treatment NC) was characterized by nearly absolute stability of all the investigated variables for the whole duration of the experiment. This stability was expected since small fluctuations in terms of number and biomass represent a well known feature of natural bacterial communities under stable environmental condition (Jürgens \& Güde 1994), suggesting the existence of buffering mechanisms probably generated by the interaction of top-down and bottom-up factors. This condition of the natural community was not unexpected since the stability model developed by Šimek et al. (2002) predicts relatively stable communities when predation pressure and resources availability constantly interplay with equal impacts.

About $40 \%$ (50\% in biovolume) of the whole natural bacterial community was composed by morphologically Edible cells, ideal food for most of the protistan predators, while the rest were inedible or less edible forms, with large predominance of very small cells, with biovolume $<0.07 \mu \mathrm{m}^{3}$. Bacterial and eukaryotic diversity was rather constant, leading us to conclude that the microbial community in the natural control was in a 
quasi-steady state for the whole duration of our experiment.

A large number of very small bacteria was found in all samples but the NP treatment. Here medium sized free-living bacteria replaced these forms, usually known as low-productive Small cells. Despite a number of studies pointed out the resistance of small bacteria to grazing by nanoflagellates both in laboratory experiments (Hahn \& Höfle 1999; Hahn et al. 2003), and in situ microcosms (Jezbera et al. 2006), these Small cells are usually considered as successful in oligotrophic systems simply because they are well adaptable to shortage in nutrients. In our experiment, these cells were not only outcompeted by larger bacteria in absence of predators, but resulted as well preserved in treatments were grazing pressure was enhanced. It is then possible to affirm that grazing contributes to the ecological success of small bacteria in a non-negligible way when compared to nutrient limitation.

In treatment NP the absence of predation promoted higher competition for the resources among different bacterial strains, resulting in a constant reduction of the community's relative diversity. Nevertheless, some OTUs increased their relative importance, while in NC they were either reduced or remained at similar proportions. Removing the predators we highly simplify the microbial community and we drastically cut down the interactions supporting the diversity in the microbial systems. The low number of interactions supported a limited number of ecological niches, likely occupied by a few, very specialized organisms (probably in our case the bacteria most active in substrate uptake). Similar conclusions were reached by Bohannan \& Lenski (2000) who demonstrated, in laboratory microcosms, that increasing bacterial productivity resulted in an increase in the relative importance of competition (bottom-up effects) as opposed to predation as a determinant of bacterial community composition.

In treatment $10 \mathrm{P}$, a simple prey-predator system that augmented the most voracious bacterial predators (the nanoflagellates and the smallest ciliates) was built, allowing a test of the response of the bacterial community to high grazing pressure. Protist predation is expected to promote a shift in the size-structure of bacterial assemblages towards extreme bacterial sizes: very small cells, large aggregates and long cells (Jürgens \& Güde 1994). The reduction of total bacterial abundance (and even more profoundly in biovolume) in 10P should be considered a response to a considerable increase in protist number and thus in predatory activity. Because of the nutrient-limiting conditions of our system, increased grazing pressure by protists only partially resulted in a bloom of protist-inedible Filaments or microcolony forming bacteria as has commonly been observed in the spring communities of productive (Pernthaler et al. 2004) and acidified lakes (Vrba et al. 2003). In nutrient-rich systems the growth of large forms of resistant bacteria can completely compensate for overall losses in bacterial biomass due to grazing mortality (Šimek et al. 1997; Posch et al. 1999; Corno \& Jürgens 2006). In our microcosms Filaments formed after grazing activity accounted for only about $15 \%$ of total abundance (but $65 \%$ in biovolume), while Aggregates and Small cells reached more than $65 \%$ (but only $25-30 \%$ in biovolume).

The Shannon diversity of the bacterial community was constant in 10P (and practically identical to NC), while diversity of the eukaryotic community was significantly reduced. The maintenance of bacterial diversity under high grazing pressure is partially in contrast to the model presented by Thingstad (2000) where viruses are mainly responsible for depleting the largest and most rapidly growing bacterial populations in mixed assemblages (killing the winner strategy), thus supporting the diversity of the bacterial community, while protistan predation can act on less abundant bacteria. Weinbauer et al. (2007) found a reduction in bacterial diversity and increases in viral production when predation by flagellates rose in mesotrophic systems. Although we did not consider the impact of the viral component, we can speculate that, in our system, the interaction between top-down and bottom-up factors provides new niches, enhancing the bacterial diversity. Our supposition is supported by the analyses of OTUs and size-structure distribution: many OTUs decreased in relative importance compared to in the natural control while others even disappeared. At the same time, many other OTUs increased in relative importance: the bacterial community at the end of the experiment was rather different from the community at the beginning, although as diverse.

It is possible to speculate that in treatment $50 \mathrm{P}$, larger predators preyed on smaller ones as well as bacteria. The experimental results suggested that nano-flagellates could be the most affected, as is generally the case (Jürgens \& Güde 1994; Pernthaler et al. 1996). Predation pressure by protists on bacteria in the 50P treatment was slightly (but significantly) lower than in $10 \mathrm{P}$, as was protist abundance. Larger predators are usually much less selective than protists as bacterivores (Chrzanowski \& Šimek 1993; Jürgens 1994). In the 50P treatment, eukaryotic diversity remained high, almost comparable in absolute values to the diversity in natural control. Bacterial abundance was reduced, and bacterial relative diversity did not follow any trend, dropping until day 9, to rise again, strongly, at the end. Sizestructure distribution also indicated that grazing-resistant rather than edible bacteria were favoured, but their representation was never higher than $24 \%$ (plus about $50 \%$ of small and very small bacterial cells). OTU 643 , which was usually abundant but totally eliminated in $10 \mathrm{P}$, was able to persist in $50 \mathrm{P}$, demonstrating that it requires the presence of intermediate and higher predators for its survival. 


\subsection{Relative OTU diversity in relation to predation and size-structure distribution}

Several studies on artificial systems (Jürgens et al. 1999; Hahn \& Höfle 2001) have concluded that the impact of protistan grazing on bacterial community composition is greater when nutrients are limiting. In agreement with this conclusion the top-down manipulations we did in P-limited microcosms highly impacted bacterial abundance and biovolume (both dramatically reduced by the activity of the selected predators in the treatments), as well as bacterial community composition and size-structure distribution of bacterial cells. Topdown manipulations (e.g., size fractionation) have been shown to alter the balance between bacterial production and mortality (Šimek et al. 1999), and to instigate shifts in bacterial community composition in mesotrophic freshwaters, too (Šimek et al. 2002).

The dramatic changes in the size-structure distribution of the bacterial communities in the microcosms was accompanied by a strong alteration in OTU distribution. Raising predation pressure resulted in a obvious advantage for a group of OTUs probably able to develop resistance strategies, maintaining a certain degree of morphological plasticity as confirmed by the proximity to the morphological classes of Filaments and Aggregates. At the same time, with low predation pressure other OTUs, probably more competitive in substrate uptaking, were clearly favoured. Moreover it is possible to divide the bacterial Group 1 of RDA analysis (Fig. 6A) in two subgroups, one composed by OTUs closely related to a morphology of medium sized free living cells, and a second one composed predominantly by Small cells. It is interesting to notice how nearly all the most prominent OTUs can be classified as A (nutrient uptake) or B (grazing resistance) specialists, but in fact, all of them are commonly present in NC. Finally, a strong positive correlation can be observed between predation pressure and relative bacterial diversity. It is then clear the importance of protistan predation in such kind of nutrient-limited systems, where the activity of grazers strongly reduce the competition for the substrate: directly, by removing part of the bacterial assemblages (the free-living medium-sized Edible cells, which are usually the most competitive in nutrient uptake), and indirectly, by releasing nutrient-rich exudates during grazing. Interestingly, also the eukaryotic relative diversity and the protistan predation on bacteria (Fig. 6B) resulted negatively correlated. This correlation is explained by the fact that as for bacteria treatment NP was free from predators, treatment $10 \mathrm{P}$ was predatorsfree for HNF and other small protists: in both these systems a reduction of ecological niches due to the reduction of limiting factors acting together, resulted in a simplification of the community and thus in a reduction of the diversity. Moreover, eukaryotic OTUs successful at high grazing activity (Fig. 6B, Group 1) resulted as rather different than OTUs successful at lower degree of grazing. Under high protistan grazing pressure, there was a clear shift in bacterial community composition regarding both size-structure distribution and genotypes. Nevertheless, diversity was preserved. The opposite situation characterized the predator-free bacterial communities; a clear and constant reduction of the community diversity was indicated, confirming that moderate top-down control is fundamental to the shaping and preservation of natural bacterial communities, even in oligotrophic systems.

\section{ACKNOWLEDGMENTS}

We thank J. Pernthaler for his valuable feedback on drafts of the manuscript, A. Marchetto for suggestions on the statistical approach, A. Hämmerli, S. Galafassi and the members of the CNR - Institute of Ecosystem Study laboratories of chemistry and microbial ecology for their help in field and laboratory work. We are grateful to S.N. Levine for editing to make the manuscript more readable in English.

\section{REFERENCES}

Bedo, A.W., J.L. Acuna, D. Robins \& R.P. Harris. 1993. Grazing in the micron and the submicron particle-size range - The case of Oikopleura dioica (Appendicularia). Bull. Mar. Sci., 53: 2-14.

Bertoni, R., R. Piscia \& C. Callieri. 2004. Horizontal heterogeneity of seston, organic carbon and picoplankton in the photic zone of Lago Maggiore, Northern Italy. J. Limnol., 63: 244-249.

Boenigk, J., \& H. Arndt. 2002. Bacterivory by heterotrophic flagellates: community structure and feeding strategies. Antonie Van Leeuwenhoek, 81: 465-480.

Boenigk, J., P. Stadler, A. Wiedlroither \& M.W. Hahn. 2004. Strain-Specific Differences in the Grazing Sensitivities of Closely Related Ultramicrobacteria Affiliated with the Polynucleobacter Cluster. Appl. Environ. Microbiol., 70: 5787-5793.

Bohannan, B.J.M. \& R.E. Lenski. 2000. Linking genetic change to community evolution: insights from studies of bacteria and bacteriophage. Ecol. Lett., 3: 362-377.

Callieri, C. \& S. Heinimaa. 1997. Microbial loop in the large subalpine lakes. Mem. Ist. ital. Idrobiol., 56: 143-156.

Callieri, C. S.M. Karjalainen \& S. Passoni. 2002. Grazing by ciliates and heterotrophic nanoflagellates on picocyanobacteria in Lago Maggiore, Italy. J. Plankton Res., 24: 785-796.

Chrzanowski, T. H. \& K. Šimek. 1993. Bacterial-Growth and Losses Due to Bacterivory in a Mesotrophic Lake. $J$. Plankton Res., 15: 771-785.

Corno, G. 2006. Effects of nutrient availability and Ochromonas sp predation on size and composition of a simplified aquatic bacterial community. Fems Microbiol. Ecol., 58: 354-363.

Corno, G. \& K. Jürgens. 2006. Direct and indirect effects of protist predation on population size structure of a bacterial strain with high phenotypic plasticity. Appl. Environ. Microbiol., 72: 78-86.

Danovaro, R., G.M. Luna, A. Dell'Anno \& B. Pietrangeli. 2006. Comparison of two fingerprinting techniques, terminal restriction fragment length polymorphism and automated ribosomal intergenic spacer analysis, for determination of bacterial diversity in aquatic environments. Appl. Environ. Microbiol., 72: 5982-5989. 
Fisher, M.M. \& E.W. Triplett. 1999. Automated approach for ribosomal intergenic spacer analysis of microbial diversity and its application to freshwater bacterial communities. Appl. Environ. Microbiol., 65: 4630-4636.

Gasol, J.M., C. Pedròs-Aliò \& D. Vaque. 2002. Regulation of bacterial assemblages in oligotrophic plankton systems: results from experimental and empirical approaches. Antonie Van Leeuwenhoek, 81: 435-452.

Gili, J.M. \& R. Coma. 1998. Benthic suspension feeders: their paramount role in littoral marine food webs. Trends Ecol. Evol., 13: 316-321.

Hahn, M.W. \& M.G. Höfle. 1999. Flagellate predation on a bacterial model community: Interplay of size-selective grazing, specific bacterial cell size, and bacterial community composition. Appl. Environ. Microbiol., 65: 48634872.

Hahn, M.W. \& M.G. Höfle. 2001. Grazing of protozoa and its effect on populations of aquatic bacteria. Fems Microbiol. Ecol., 35: 113-121.

Hahn, M.W., H. Lunsdorf, Q.L. Wu, M. Schauer, M.G. Höfle, J. Boenigk \& P. Stadler. 2003. Isolation of novel ultramicrobacteria classified as Actinobacteria from five freshwater habitats in Europe and Asia. Appl. Environ. Microbiol., 69: 1442-1451.

Hewson, I. \& J.A. Fuhrman. 2004. Richness and diversity of bacterioplankton species along an estuarine gradient in Moreton Bay, Australia. Appl. Environ. Microbiol., 70: 3425-3433.

Hunt, D.E., V. Klepac-Ceraj, S.G. Acinas, C. Gautier, S. Bertilsson \& M.F. Polz. 2006. Evaluation of 23S rRNA PCR primers for use in phylogenetic studies of bacterial diversity. Appl. Environ. Microbiol., 72: 2221-2225.

Jezbera, J., K. Hornak \& K. Simek. 2006. Prey selectivity of bacterivorous protists in different size fractions of reservoir water amended with nutrients. Environ. Microbiol. 8: 1330-1339.

Jürgens, K. 1994. Impact of Daphnia on planktonic microbial food webs - a review. Mar. Microb. Food Webs, 8: 295324.

Jürgens, K. \& H. Güde. 1994. The Potential Importance of Grazing-Resistant Bacteria in Planktonic Systems. Mar. Ecol. Prog. Ser., 112: 169-188.

Jürgens, K., J. Pernthaler, S. Schalla \& R. Amann. 1999. Morphological and compositional changes in a planktonic bacterial community in response to enhanced protozoan grazing. Appl. Environ. Microbiol., 65: 1241-1250.

Kirchman, D., H. Ducklow, \& R. Mitchell. 1982. Estimates of bacterial growth from changes in uptake rates and biomass. Appl. Environ. Microbiol., 44: 1296-1307

Lee, S., Y.C. Kang \& J.A. Fuhrman. 1995. Imperfect retention of natural bacterioplankton cells by class-fiber filters. Mar. Ecol. Prog. Ser., 119: 285-290.

Luna, G.M., A. Dell'Anno \& R. Danovaro. 2006. DNA extraction procedure: a critical issue for bacterial diversity assessment in marine sediments. Environ. Microbiol., 8: 308-320.

Manca, M., A. Visconti, R. Piscia, \& R. de Bernardi. 2007. Zooplancton. In: CNR Istituto per lo Studio degli Ecosistemi (Ed.), Ricerche sull'evoluzione del Lago Maggiore. Aspetti Limnologici. Programma quinquennale 20032007. Campagna 2005. Commissione Internazionale per la protezione delle acque italo-svizzere: 60-63.

Massana, R., J.M. Gasol, P.K. Bjornsen, N. Blackburn, A. Hagstrom, S. Hietanen, B.H. Hygum, J. Kuparinen \& C. Pedròs-Aliò. 1997. Measurement of bacterial size via image analysis of epifluorescence preparations: description of an inexpensive system and solutions to some of the most common problems. Sci. Mar., 61: 397-407.

Massana, R. \& K. Jürgens. 2003. Composition and population dynamics of planktonic bacteria and bacterivorous flagel- lates in seawater chemostat cultures. Aquat. Microb. Ecol., 32: 11-22.

Massana, R., C. Pedros Alio, E.O. Casamayor \& J.M. Gasol. 2001. Changes in marine bacterioplankton phylogenetic composition during incubations designed to measure biogeochemically significant parameters. Limnol. Oceanogr., 46: 1181-1188.

Matz, C. \& S. Kjelleberg. 2005. Off the hook - how bacteria survive protozoan grazing. Trends Microbiol., 13: 302307.

Morabito, G., A. Oggioni, E. Caravati \& P. Panzani. 2007. Seasonal morphological plasticity of phytoplankton in Lago Maggiore (N. Italy). Hydrobiologia, 578: 47-57.

Osborn, A.M., E.R.B. Moore \& K.N. Timmis. 2000. An evaluation of terminal-restriction fragment length polymorphism (T-RFLP) analysis for the study of microbial community structure and dynamics. Environ. Microbiol., 2: $39-50$.

Paul, J.H. \& B. Myers. 1982. Fluorometric determination of DNA in aquatic microorganisms by use of Hoechst 33258. Appl. Environ. Microbiol., 43: 1393-1399.

Pernthaler, J. 2005. Predation on prokaryotes in the water column and its ecological implications. Nat. Rev. Microbiol., 3: 537-546.

Pernthaler, J., T. Posch, K. Simek, J. Vrba, R. Amann \& R. Psenner. 1997. Contrasting bacterial strategies to coexist with a flagellate predator in an experimental microbial assemblage. Appl. Environ. Microbiol., 63: 596-601.

Pernthaler, J., T. Posch, K. Šimek, J. Vrba, A. Pernthaler, F. O. Glöckner, U. Nübel, R. Psenner \& R. Amann. 2001. Predator-specific enrichment of actinobacteria from a cosmopolitan freshwater clade in mixed continuous culture. Appl. Environ. Microbiol., 67: 2145-2155.

Pernthaler, J., B. Sattler, K. Šimek, A. Schwarzenbacher \& R. Psenner. 1996. Top-down effects on the size-biomass distribution of a freshwater bacterioplankton community. Aquat. Microb. Ecol., 10: 255-263.

Pernthaler, J., E. Zöllner, F. Warnecke \& K. Jürgens. 2004. Bloom of Filamentous Bacteria in a Mesotrophic Lake: Identity and Potential Controlling Mechanism. Appl. Environ. Microbiol., 70: 6272-6281.

Posch, T., K. Šimek, J. Vrba, S. Pernthaler, J. Nedoma, B. Sattler, B. Sonntag \& R. Psenner. 1999. Predator-induced changes of bacterial size-structure and productivity studied on an experimental microbial community. Aquat. Microb. Ecol., 18: 235-246.

Ramette, A. 2007. Multivariate analyses in microbial ecology. Fems Microbiol. Ecol., 62: 142-160.

Salmaso, N., G. Morabito, R. Mosello, L. Garibaldi, M. Simona, F. Buzzi \& D. Ruggiu. 2003. A synoptic study of phytoplankton in the deep lakes south of the Alps (lakes Garda, Iseo, Como, Lugano and Maggiore). J. Limnol., 62: 207-227.

Salmaso, N., G. Morabito, L. Garibaldi, \& R. Mosello. 2007. Trophic development of the deep lakes south of the Alps: a comparative analysis. Arch. Hydrobiol., 170: 177-196.

Sanders, R.W., D.A. Caron \& U.G. Berninger. 1992. Relationships between Bacteria and Heterotrophic Nanoplankton in Marine and Fresh Waters - an Inter-Ecosystem Comparison. Mar. Ecol. Prog. Ser., 86: 1-14.

Sherr, B.F., E.B. Sherr \& J. McDaniel. 1992. Effect of protis$\tan$ grazing on the frequency of dividing cells in bacterioplankton assemblages. Appl. Environ. Microbiol., 58: 2381-2385.

Sherr, E.B., \& B.F. Sherr. 1987. High rates of consumption of bacteria by pelagic ciliates. Nature, 325: 710-711.

Shimeta, J. \& P.A. Jumars. 1991. Physical mechanisms and rates of particle capture by suspension-feeders. Oceanogr. Mar. Biol. Ann. Rev., 29: 191-257.

Šimek, K., K. Hornak, M. Masin, U. Christaki, J. Nedoma, M. G. Weinbauer \& J. R. Dolan. 2003. Comparing the effects 
of resource enrichment and grazing on a bacterioplankton community of a meso-eutrophic reservoir. Aquat. Microb. Ecol., 31: 123-135.

Šimek, K., P. Kojecka, J. Nedoma, P. Hartman, J. Vrba \& J. R. Dolan. 1999. Shifts in bacterial community composition associated with different microzooplankton size fractions in a eutrophic reservoir. Limnol. Oceanogr., 44: 1634-1644.

Šimek, K., J. Nedoma, J. Pernthaler, T. Posch \& J. R. Dolan. 2002. Altering the balance between bacterial production and protistan bacterivory triggers shifts in freshwater bacterial community composition. Antonie Van Leeuwenhoek, 81: 453-463.

Šimek, K., J. Pernthaler, M.G. Weinbauer, K. Hornak, J.R. Dolan, J. Nedoma, M. Masin \& R. Amann. 2001. Changes in bacterial community composition and dynamics and viral mortality rates associated with enhanced flagellate grazing in a mesoeutrophic reservoir. Appl. Environ. Microbiol., 67: 2723-2733.

Šimek, K., J. Vrba, J. Pernthaler, T. Posch, P. Hartman, J. Nedoma \& R. Psenner. 1997. Morphological and compositional shifts in an experimental bacterial community influenced by protists with contrasting feeding modes. Appl. Environ. Microbiol., 63: 587-595.

Taguchi, S. \& E.A. Laws. 1988. On the micro-particles which pass through glass-fiber filter type GF/F in coastal, and open waters. J. Plankton Res., 10: 999-1008. ter Braak, C.J.F., \& P. Smilauer.1998. CANOCO for Windows: Software for canonical Community Ordination. Microcomputer Power, Ithaca

Thingstad, T.F. 2000. Elements of a theory for the mechanisms controlling abundance, diversity, and biogeochemical role of lytic bacterial viruses in aquatic systems. Limnol. Oceanogr., 45: 1320-1328.

Thingstad, T.F. \& R. Lignell. 1997. Theoretical models for the control of bacterial growth rate, abundance, diversity and carbon demand. Aquat. Microb. Ecol., 13: 19-27.

Thingstad, T.F., L. Ovreas, J.K. Egge, T. Lovdal \& M. Heldal. 2005. Use of non-limiting substrates to increase size; a generic strategy to simultaneously optimize uptake and minimize predation in pelagic osmotrophs? Ecol. Lett., 8: 675-682.

Vrba, J., J. Nedoma, L. Kohout, J. Kopacek, L. Nedbalova, P. Rackova \& K. Simek. 2003. Massive occurrence of heterotrophic filaments in acidified lakes: seasonal dynamics and composition. Fems Microbiol. Ecol., 46: 281-294.

Weinbauer, M.G., K. Hornak, J. Jezbera, J. Nedoma, J.R. Dolan \& K. Simek. 2007. Synergistic and antagonistic effects of viral lysis and protistan grazing on bacterial biomass, production and diversity. Environ. Microbiol., 9: 777-788.

Weisse, T. 1999. Bacterivory in the northwestern Indian Ocean during the intermonsoon northeast monsoon period. Deep-Sea Res. Part II, 46: 795-814.

Received: March 2008

Accepted: June 2008 